\section{Basic and Applied Ecology}

www.elsevier.de/baae

\title{
Dung beetles as secondary seed dispersers in a temperate grassland
}

\author{
Bram D'hondt ${ }^{\mathrm{a}, *}$, Beatrijs Bossuyt ${ }^{\mathrm{a}}$, Maurice Hoffmann ${ }^{\mathrm{a}, \mathrm{b}}$, Dries Bonte ${ }^{\mathrm{a}}$ \\ ${ }^{a}$ Terrestrial Ecology Unit, Biology Department, Ghent University, K.L. Ledeganckstraat 35, B-9000 Ghent, Belgium \\ ${ }^{\mathrm{b}}$ Ecosystems Department, Research Institute for Nature and Forest, Kliniekstraat 25, B-1070 Brussels, Belgium
}

Received 13 December 2006; accepted 11 November 2007

\begin{abstract}
The two-phase dispersal event in which dung beetles move seeds after endozoochory is often assumed to be advantageous for plant regeneration. Because seeds are expected to end up in favourable and safe germination sites, it is considered as an example of directed dispersal. However, literature so far is restricted to tropical rain forest ecosystems, while data for temperate regions are lacking. In this study, the effect of dung beetles on seedling establishment of endozoochorically dispersed seeds is evaluated for a temperate grassland ecosystem. We performed a field experiment in which cages excluded dung beetles from horse and cattle dung samples with mixed-in grass seeds. Seed germination from these samples was significantly higher than that from samples which were accessible to dung beetles. This indicates that the effect of dung beetles on short-term seedling establishment was negative, which contrasts with the patterns found for large-seeded species used in tropical studies. This is most likely attributed to the lack of roller species and the larger depth at which tunneling Geotrupes species bury seeds.
\end{abstract}

(C) 2007 Gesellschaft für Ökologie. Published by Elsevier GmbH. All rights reserved.

\section{Zusammenfassung}

Eine zweiphasige Ausbreitung, bei der Samen im Anschluss an endozoochoren Transport von Dungkäfern weiterbewegt werden, wird oft als günstig für die pflanzliche Regeneration angenommen. Da man vermutet, dass die Samen günstige und sichere Keimungsplätze erreichen, wird dies als Beispiel für eine gerichtete Ausbreitung angesehen. Die Literatur beschränkt sich auf tropische Regenwälder, während Daten für gemäßigte Regionen fehlen. In dieser Studie wird der Effekt von Dungkäfern auf die Etablierung von Keimlingen aus endozoochor verbreiteten Samen in einem Grasland-Ökosystem untersucht. Wir führten ein Freilandexperiment durch, bei dem die Dungkäfer durch Käfige von Pferde- bzw. Rinderdungproben, denen Grassamen beigemischt waren, ferngehalten wurden. Die Samenkeimung von diesen Proben war signifikant höher als die von Proben, die den Dungkäfern zugänglich gewesen waren. Dies deutet darauf hin, dass die Dungkäfer die Etablierung von Keimlingen im engeren Zeitrahmen negativ beeinflussten, was im Gegensatz zu Ergebnissen steht, die in tropischen Studien mit großsamigen Arten gefunden wurden. Höchstwahrscheinlich ist dies auf das Fehlen von Pillendrehern zurückzuführen, sowie auf die größere Tiefe, in die die grabenden Geotrupes-Arten die Samen verfrachten. (C) 2007 Gesellschaft für Ökologie. Published by Elsevier GmbH. All rights reserved.

Keywords: Seed dispersal; Secondary dispersal; Diplochory; Seed burial; Agrostis; Poa

\footnotetext{
${ }^{*}$ Corresponding author. Tel.: + 32 92645086; fax: +3292648794

E-mail address: b.dhondt@ugent.be (B. D’hondt).
} 


\section{Introduction}

Acting as dispersal agents, animals may take plant seeds to non-random microhabitats that are well-suited for establishment and growth. This process, referred to as 'directed dispersal', was distinguished by Howe and Smallwood (1982) as one of three major advantages of seed dispersal, and is assumed to be more common than formerly thought (Wenny, 2001). Directed dispersal is considered to be a key step in diplochory (Vander Wall \& Longland, 2004), in which seeds are dispersed in two successive phases, each involving a different dispersal agent. According to Vander Wall and Longland (2004), the benefits offered by the different phases differ: second phase dispersers (e.g. ants, rodents, corvids) take seeds to microsites that are more suitable for establishment than those reached by phase one dispersers (e.g. wind, herbivores). One particular case of diplochory occurs when dung beetles act as secondary dispersers of seeds contained in vertebrate dung.

Within the dung beetles (coprophilous species within the Scarabaeidae subfamilies Aphodiinae, Geotrupinae and Scarabaeinae [classification following Janssens, 1949, 1960]), three functional groups are distinguished: dwellers, tunnelers and rollers (Cambefort \& Hanski, 1991). Aphodiinae are predominantly dwellers: these small-sized beetles (generally less than $10 \mathrm{~mm}$ in length) eat their way through the dung and deposit their eggs without constructing a nest or chamber. Geotrupinae and most Scarabaeinae are tunnelers: they dig a more or less vertical tunnel beneath a dung pat and move the dung to the shaft base. Many Scarabaeinae, specified as rollers, construct a dung ball and transport this over a distance prior to burying it (telecoprid nidification sensu Bornemissza, 1969). Dung beetles do not eat seeds (Andresen \& Feer, 2005), so tunnelers and rollers may contribute to directed dispersal by moving and burying seeds along with the dung.

So far, studies on secondary seed dispersal by dung beetles and its influence on plant regeneration almost exclusively focused on tropical rain forest ecosystems. In a review, Andresen and Feer (2005) concluded that burial has both a positive impact through lower seed predation and a negative impact through decreased seedling emergence. Little is known, however, about the net outcome of these antagonistic effects. Only Andresen and Levey (2004) really followed the fate of seeds placed in dung until seedling establishment in a (Central Amazonian) rain forest ecosystem. Their results, concerning 11 large-seeded tree species and howler monkey dung, indicated that seeds buried by dung beetles were on average twice as likely to become seedlings than unburied seeds. In the only study investigating dung beetle mediated seed dispersal outside tropical regions we know about, Wicklow, Kumar, and Lloyd (1984) found a subtropical roller species (Kohlmann, 1991) to facilitate seedling establishment of a prairie grass species in North America.

More studies are needed to ascertain if this positive effect also holds for other climate regions and ecosystems (Andresen \& Feer, 2005), because it is reasonable to assume that important differences in the dung beetle communities or the plant species involved may lead to deviant patterns. For instance, at lower latitudes dung beetle communities are dominated by rolling or tunneling Scarabaeinae, whereas the northern temperate regions are characterized by a dominance of the dwelling genus Aphodius (Aphodiinae), normally accompanied by one or a few species of tunneling Geotrupinae (Hanski, 1991).

In this study, we aim to test the hypothesis that dung beetle activity has an overall positive effect on successful germination of seeds present in dung in a temperate coastal dune ecosystem. A field experiment was constructed, in which the effect of dung beetle presence on short-term seedling establishment from horse and cattle dung was tested. This 'main experiment' was supplemented by some supplementary experiments, i.e. controls to evaluate the main setup in detail and a study of the dung beetle fauna present within.

\section{Materials and methods}

\section{Study area and local dung beetle assemblage}

The field experiment was set up in the nature reserve 'Westhoek' (Belgium, 51 $04^{\prime} 50^{\prime \prime} \mathrm{N}-2^{\circ} 34^{\prime} 19^{\prime \prime} \mathrm{E}$ ), consisting of over 340 ha of coastal dune landscape. It is characterized by a spatially heterogeneous mosaic of open dunes, grey dunes, grassland, shrub and woodland. Since 1996, part of the area is grazed by cattle and several equine breeds, restoring extensive grazing previously maintained by livestock. In a recent study of the associated dung beetle fauna, 15 species were found (Struyve, 2002), 12 of which belong to the dweller genus Aphodius Illiger. Onthophagus similis Scriba, Geotrupes niger Marsham and Geotrupes spiniger Marsham were the tunneler species found. No roller species were present in the area. Hence, functionally, the overall dung beetle fauna can be considered as typical of a temperate ecosystem (Hanski, 1991).

\section{Main experiment}

At each of two grassland sites within the study area, the effect of dung beetle activity on seed germination was assessed using the same experimental randomized block design. The sites consisted of preliminary mown grasslands located within livestock-excluding fences, the 
surroundings of which were grazed by cattle as well as ponies.

One site is distinctly moister than the other: from September 2005 to April 2006, ground water fluctuated between 0.2 and $1.0 \mathrm{~m}$ beneath the surface at the moist site and between 1.5 and $2.1 \mathrm{~m}$ at the dry site (De Becker, Van Daele, Huybrechts, Provoost, \& Leten, unpublished).

Perpendicular to the prevailing moisture gradient at each site, six strips of $1 \mathrm{~m}$ width were delimited, which contained (among others [i.e. controls, see below]) eight sod-cut plots $(50 \times 50 \mathrm{~cm}, 25 \mathrm{~cm}$ inter-plot spacing), on which treated dung samples were deposited, the treatments being allocated at random within a strip (block).

Dung was collected from horses (Konik) and cattle (Galloway) that were fed a seed-free diet in captivity. In September 2005, two-litre samples were deposited on the field plots, and simultaneously, 100 seeds, either from Agrostis capillaris L. or Poa pratensis L., were mixed into each sample. Dispersules were on average $1.60 \mathrm{~mm}$ in length for A. capillaris and $2.78 \mathrm{~mm}$ for P. pratensis ( $n=20$ each, seeds plus glumes). Cosyns, Claerbout, Lamoot, and Hoffmann (2005) found both grasses to be viably present in dung of cattle, horses and ponies in the 'Westhoek' reserve. Period of seed set is August to October for the former, and August for the latter (Grime, Hodgson, \& Hunt, 1988).

After deposition in the field, half of the dung samples were caged ('closed cage'), making the dung inaccessible to dung beetles $(1.25 \mathrm{~mm}$ mesh), while the others were equipped with an 'open cage', covering the top and the southern side of the plot and leaving all other lateral sides open, enabling dung beetles to gain access to the samples easily.

During September and October 2005 - the months in which dung samples were subject to dung beetle colonization - precipitation rates were normal, but temperatures were exceptionally high (in September, mean temperature was $16.0^{\circ} \mathrm{C}$ instead of $14.2^{\circ} \mathrm{C}$, October: $14.4^{\circ} \mathrm{C}$ instead of $10.6{ }^{\circ} \mathrm{C}$; recorded at $\pm 20 \mathrm{~km}$ off; Malcorps, 2005a, b).

About 73 days after deposition, in November-December 2005, the number of seedlings of either A. capillaris or $P$. pratensis was counted on each dung pat once. Seedlings were removed after counting. An additional count was conducted in the following spring (April 2006), but very few seedlings could be added. Visual traces of dung beetle activity were recorded, in particular, tunneling by Geotrupes, which was recognized by the presence of tunnel entrances surrounded by bare sand.

\section{Germination controls}

To test whether the obtained dung was free from seeds, a greenhouse control experiment was performed in which germination from six untreated dung samples per herbivore type $(2 \mathrm{~L})$ was monitored. These were deposited on a sand-peat substrate mixture, subjected to a 16-h light:8-h dark regime, and watered manually (September-December 2005).

In order to test the used grass seeds for their viability, we determined germination of 6 times 100 seeds per species in two controls: once in the field, once in the greenhouse. In both, seeds were sown in sand-peat substrate (which, in the field, was spread out within cageless sod-cut plots; September-December).

Moreover, the effect of both 'open' and 'closed cage' constructions on germination conditions was tested in the greenhouse by sowing seeds in the same substrate, with six replicates for every combination of cage type and plant species (September-December).

\section{Dung beetle fauna}

To assess the species composition of the dung beetle community in the study area, six horse dung and six cattle dung samples were deposited at both sites and contiguously encircled by five pitfall traps per sample ( $65 \mathrm{~mm}$ diameter, $\pm 80 \mathrm{~mm}$ spacing between). Half of these samples were fitted with 'open cages' while the other remained cageless, in order to determine whether the dung beetle fauna visiting the 'open cages' was representative of the cageless, i.e. natural situation.

During a 63-day period (mid-September to midNovember 2005), all Scarabaeidae were gathered, identified up to the species level (Janssens, 1960) and classified as tunnelers (Geotrupes spp., Onthophagus spp.) or dwellers (Aphodius spp.).

\section{Data analysis}

In the main experiment, Dung type, Plant species, Site and Cage type were subsequently used as fixed factors in two separate Mixed Models, in each case with seedling numbers ('successful germination') as the dependent variable. In the first, 'open' and 'closed cages' were the Cage type levels, while in the second analysis the 'open cages' group was split up in two: with and without traces of tunnelers. In both models, the correction for location of a plot according to the prevalent moisture gradient was made by incorporating the position of the strip it was in as a random factor (AR(1)-structured; Littell, Milliken, Stroup, \& Wolfinger, 1996). We started from the full model, and used a backward procedure by stepwise eliminating non-significant contributions to reach the reduced models presented here.

To analyse the dung beetle fauna gathered in the pitfalls, we used General Linear Models to evaluate densities (instead of Mixed Models, as the corrections for location proved not to contribute significantly) and 
an ordination technique to evaluate composition. In the linear models, the total number of dung beetles per sample and the numbers of dwellers and tunnelers were used as dependent variables. The fixed factors Cage type, Dung type, Site (and interactions) were used as independent variables. Species composition was analysed by detrended correspondence analysis (DCA), following suggestions of McCune and Grace (2002) on the determination coefficient $\left(r^{2}\right)$. Rare species (occurrence in less than 3 out of 24 samples) were removed in advance, and densities were converted to relative numbers (percentage individuals of species $x$, occurring in sample $y$ ). We then tested whether the coordinates on the axes that represented the highest proportion of variation, were significantly different between the levels within each factor, using Wilcoxon two-sample tests.

Except for the DCA, which was done using Pc-Ord 4.26 (McCune \& Mefford, 1999), statistical analyses were executed with the SAS software package (SAS Institute, 2003).

\section{Results}

\section{Dung beetle fauna}

Using the pitfall traps distributed among the 24 dung samples (12 per site), 650 Scarabaeidae individuals were caught, belonging to 12 species and 3 genera. The three most abundant species were Aphodius contaminatus Herbst (46\% of all captured individuals), A. foetens Fabricius (27\%) and G. spiniger Marsham (11\%). The only other tunnelers, $O$. similis Scriba (1\%) and G. niger Marsham $(<0.2 \%)$, were far less numerous.

Numbers of tunnelers were significantly higher for the dry site. The opposite was true for dwellers: higher numbers were found at the moist site. The total number of dung beetles did not differ between the two sites (Table 1; Fig. 1). Apparently, at the moist site the open cages had a repulsive effect on some dweller species (as opposed to the dry site), resulting in a significant interaction of these factors in the dweller, and concomitantly, the total beetle analysis. Also, when visiting horse dung, tunnelers seemed to prefer the open-caged samples, whereas visiting cow dung, cageless pats were preferred. Moreover, the three-way interaction proved significant.

In the DC-analysis, only the first axis represented a substantial portion of the variance $\left(r_{1}^{2}=0.361\right.$, gradient length $=3.241$ ). The Wilcoxon two-sample test on the sample coordinates of this axis supported the significant segregation between sites $(Z=-2.859, \quad p=0.004$; Fig. 2). This supported the use of Site as a fixed factor in the analysis of the main experiment: the one site represented a high tunneler presence, the other a low tunneler presence. Moreover, species composition differed between cattle and horse dung $(Z=-2.051$, $p=0.040$; Fig. 2), due to apparent preferences of Aphodius species (e.g. A. sphacelatus Panzer was found almost exclusively in the former, A. contaminatus in the latter).

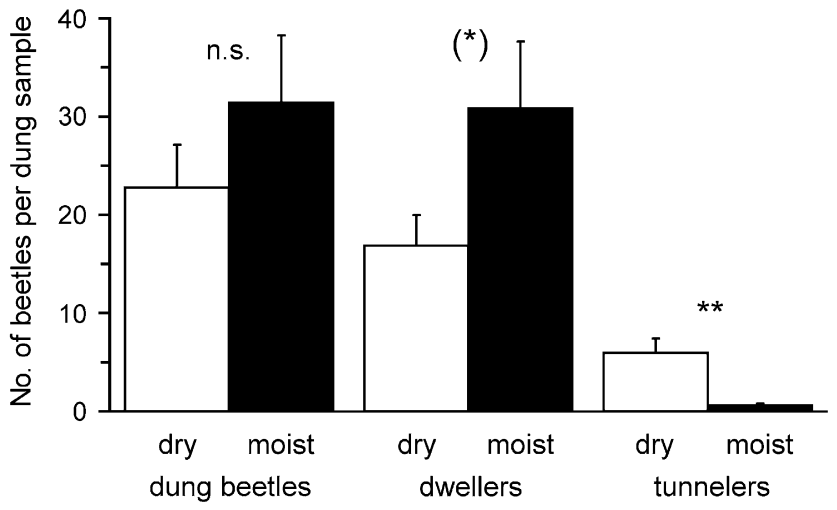

Fig. 1. Mean number ( + S.E.) of dung beetle individuals caught in the pitfalls during the study period, separated in functional groups (dwellers plus tunnelers, and both separately). n.s., $\left(^{*}\right)$ and $* *$ indicate $p>0.10, p>0.05$ and $p<0.01$, respectively, for differences between sites.

Table 1. Numbers of cases $(N)$, degrees of freedom (df), $F$-statistics $(F)$ and $p$-values $(p)$ of the General Linear Models testing for the effects of Cage type, Dung type and Site on the total number of individuals caught per dung sample

\begin{tabular}{|c|c|c|c|c|c|c|c|c|c|c|}
\hline \multirow[t]{2}{*}{ Source of variation } & \multicolumn{4}{|c|}{ Dwellers + tunnelers } & \multicolumn{3}{|c|}{ Dwellers } & \multicolumn{3}{|c|}{ Tunnelers ${ }^{\mathrm{a}}$} \\
\hline & $N_{1}, N_{2}$ & $\mathrm{df}$ & $F$ & $p$ & df & $F$ & $p$ & $\mathrm{df}$ & $F$ & $p$ \\
\hline Cage type & 12,12 & 1 & 1.45 & 0.247 & 1 & 2.22 & 0.156 & 1 & 0.31 & 0.586 \\
\hline Dung type & 12,12 & 1 & 2.28 & 0.151 & 1 & 1.77 & 0.202 & 1 & 2.78 & 0.115 \\
\hline Site & 12,12 & 1 & 2.11 & 0.166 & 1 & 7.08 & 0.017 & 1 & 19.79 & 0.000 \\
\hline Cage type $\times$ Dung type & & 1 & 1.13 & 0.304 & 1 & 3.03 & 0.101 & 1 & 5.58 & 0.031 \\
\hline Cage type $\times$ Site & & 1 & 6.91 & 0.018 & 1 & 7.59 & 0.014 & 1 & 0.95 & 0.345 \\
\hline Dung type $\times$ Site & & 1 & 0.23 & 0.641 & 1 & 0.90 & 0.356 & 1 & 3.27 & 0.090 \\
\hline Cage type $\times$ Dung type $\times$ Site & & 1 & 13.01 & 0.002 & 1 & 12.80 & 0.003 & 1 & 4.95 & 0.041 \\
\hline
\end{tabular}

${ }^{a}$ The horse dung sample on the dry site showing the highest tunneler number skewed the residual distribution to be non-normal (Shapiro-Wilk's test, $p<0.001$ ). Nonetheless, the GLM is not altered when excluding this outlier (with regard to [non-]significant factors). 

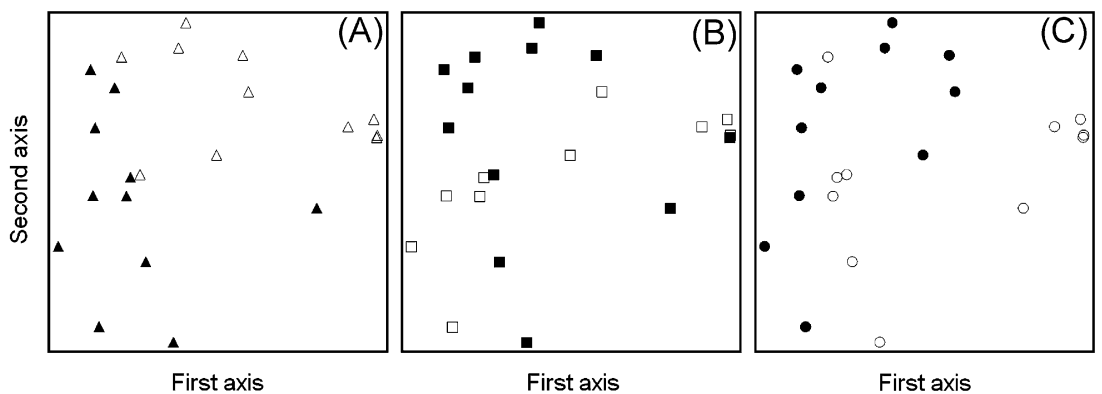

Fig. 2. DC-analysis ordination diagram. In (A), an overlay is made for the sites. Species composition significantly differs between the dry $(\mathbf{\Delta})$ and moist site $(\Delta)$. The same is true for horse dung samples $(\boldsymbol{\square})$ as compared to cattle dung samples [ $\square$; (B)], while no significant difference was found between dung samples without cages $(\mathbf{O})$ and those with open cages [O; (C)]. The coefficients of determination $\left(r^{2}\right)$ equal 0.36 and 0.19 for the first and the second axis, respectively.

Table 2. Numbers of cases $(N)$, degrees of freedom (df; numerator, denominator), $F$-statistics $(F)$ and $p$-values $(p)$ of the Mixed Models testing for the effects of Cage type, Dung type, Plant species and Site on the number of seeds germinating from dung

Source of variation Including all open cages (analysis 1) Splitting the 'open cage' level up in those with and those without tunneler traces (analysis 2)

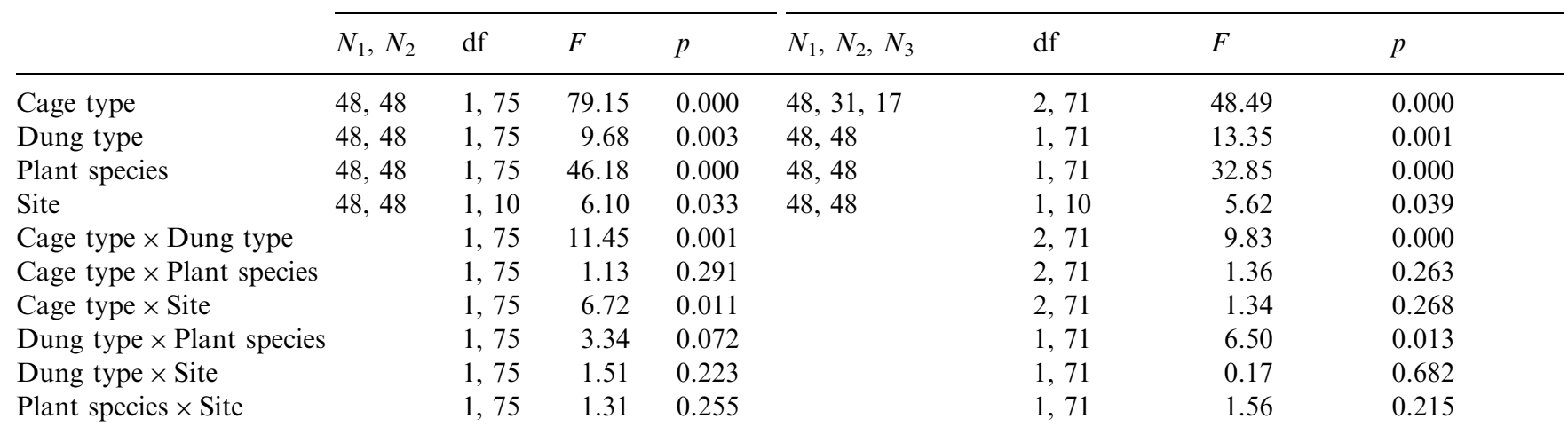

$\operatorname{AR}(1):$ estimate $=0.9108, Z=3.13$,

$\mathrm{AR}(1)$ : estimate $=0.9157, Z=3.27, p=0.001$

$$
p=0.002
$$

Densities of dung beetles did not differ between dung samples that were equipped with open cages and cageless samples (Table 1), nor did the species composition $(Z=0.664, p=0.507$; Fig. 2$)$.

\section{Germination controls}

The sites themselves apparently influenced germination differently: within the closed cages on the dry site, it was lower compared to closed cages on the moist site ( $F=11.39$, df $=1, p=0.002$, full model on closed cages data).

To a certain extent, the used dung was contaminated with seeds: on average, $16.33 \pm 9.16$ alien seedlings germinated from each horse dung sample $(n=6)$, of which $1.67 \pm 1.97$ individuals could be attributed to Poa spp. and $0.88 \pm 0.98$ to Agrostis spp. From these data, it was calculated that approximately $2.6 \%$ of the Agrostisseedlings and $4.0 \%$ of the Poa-seedlings counted in samples of the main experiment actually concerned contaminations.
From the cattle dung samples, $1.33 \pm 1.21$ alien seedlings emerged $(n=6)$, none of which were Poa or Agrostis species. Since the contamination degree was less than $5 \%$ for horse dung, and $0 \%$ for cattle, its effect was not taken into account in further analyses.

Seeds of $A$. capillaris and $P$. pratensis were sufficiently viable, as shown in the germination controls with seed deposited in sand-peat substrate in a greenhouse (A.c. $91.17 \pm 2.86 \%$; P.p. $84.50 \pm 6.53 \% ; n=6$ each) and in field conditions (A.c. $61.58 \pm 7.28 \%$; P.p. $62.00 \pm 8.21 \%$; $n=12$ each).

Cage type ('open' or 'closed cage') had no effect on germination success in controlled greenhouse conditions with the sand-peat substratum $(F=0.095, \quad \mathrm{df}=1$, $p=0.760)$.

\section{Main experiment}

For A. capillaris and $P$. pratensis sown in the dung samples, germination varied greatly, from 2 to 66 
seedlings per dung sample. There was also large variation in the degree to which dung beetles processed the dung: some samples were strongly fragmented and exhibited many dung beetle traces, while others were left intact.

Showing no significant contributions, four- and threeway interactions were stepwise eliminated from the full models, resulting in the reduced models presented in Table 2. Using all samples in the analysis, successful germination turned out to be significantly higher under closed cages than under open cages (Table 2; Fig. 3). Relative to this contrast, the difference between closed cages and the open-caged samples showing tunneler traces increased, whereas the difference with those showing no traces decreased (Table 3; Fig. 3). Thus, animals visiting open cages clearly brought about a substantial decline in seedling establishment, and this is especially true for tunnelers. Also, in both approaches, successful germination turned out to be higher on the moister than on the drier site (Table 2; Fig. 3). Overall, $P$. pratensis germinated better than $A$. capillaris, and germination from horse dung was higher than from

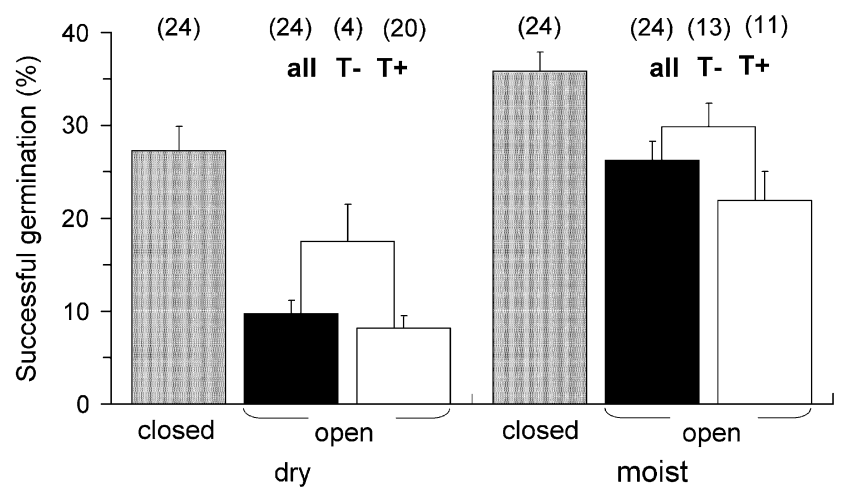

Fig. 3. The mean number $(+$ S.E. $)$ of seedlings counted in the dung samples as a function of Site and Cage type. Numbers are for Agrostis capillaris and Poa pratensis combined. Grey bars represent 'closed cages', black bars represent all 'open cages', while white bars represent 'open cages' without $(\mathrm{T}-)$ and with $(\mathrm{T}+)$ tunneler traces (thus, the combination of white bars result in the black). The numbers of samples are enclosed within brackets at the top.

Table 3. Results of the multiple comparison procedure using Tukey-Kramer adjustment

\begin{tabular}{|c|c|c|c|}
\hline & \multirow{2}{*}{$\begin{array}{l}\text { Closed cages } \\
\text { (1) }\end{array}$} & \multicolumn{2}{|l|}{ Open cages } \\
\hline & & $\begin{array}{l}\text { With tunneler } \\
\text { traces }(2)\end{array}$ & $\begin{array}{l}\text { Without tunneler } \\
\text { traces (3) }\end{array}$ \\
\hline (1) & & $<0.0001$ & 0.0210 \\
\hline (2) & $<0.0001$ & & 0.0008 \\
\hline (3) & 0.0210 & 0.0008 & \\
\hline
\end{tabular}

Given are the $p$-values. cattle dung (Table 2), which is likely due to differential nutrient requirements from the plant species, and dung textures (loose vs. compact), respectively.

\section{Discussion}

Our results show that dung-visiting fauna had a negative effect on short-term, in situ germination for the two small-seeded species in a temperate grassland situation, and this was especially true for tunnelers. Since cage type did not affect germination conditions, and the open cages allowed access of a dung beetle community representative of the study area, both in numbers and composition, this effect can be assumed representative of natural situations.

However, apart from this direct effect on seedling establishment, dung beetles may contribute to the soil seed bank: seeds may remain dormant in the soil and germinate successfully later on. If this applies to a substantial number of seeds, the interaction could prove to be positive after all. Thus, whether the event under study here can indeed be considered as directed and beneficial (Vander Wall \& Longland, 2004; Wenny, 2001), depends on the outcome on the long term. Indeed, seeds of $P$. pratensis are known to stay viable for more than 20 years, even at great burial depths (Goss, 1924).

Nonetheless, on the short-term scale, our experimental results clearly contrast the positive outcome found by Andresen and Levey (2004), who conducted the only field study following dung beetle mediated dispersal up to the point of seedling establishment until now. Evidently, differences in the dung beetle community, predator guild and/or plant species involved led to deviant patterns.

First, one of the possible dung beetle effects listed by Andresen and Feer (2005) is the reduction of seed clumping in a dung pat, and hence of seedling competition. However, this implies that seed movement by dung beetles also includes a horizontal component, which only is obvious in telecoprid nidification. Since rollers are abundant in tropical regions (cf. Andresen \& Levey, 2004) but absent from typical assemblages of northern temperate regions (Hanski, 1991), this presumed positive effect does not occur in the latter.

Second, dung processing may also affect the microclimate that seeds experience. In the case of tunnelers, buried seeds may, for instance, experience more humidity and less light relative to ground level. This may positively as well as negatively affect the probability of germination, depending on the particular requirements of each species (cf. Wicklow et al., 1984). Because of dweller activities, seeds may end up in a more favourable mixed dung-soil substrate (see Holter, 1977). 
For A. capillaris and $P$. pratensis, microclimatic effects were not considered in detail here, although a comparison between germination successes in dung (closed cages) and in sand-peat substratum hints dung to inhibit germination for both species.

Third, seed burial decreases the risk of seed predation as compared to unburied seeds. Indeed, seed removal by rodents after endozoochory is known for large-seeded plant species of tropical forests (Vander Wall \& Longland, 2004) and, anecdotically, of temperate forests (e.g. Bermejo, Traveset, \& Willson, 1998 [from bear faeces]; Page, Swihart, \& Kazacos, 2001 [raccoon faeces]). In the case of ungulates ranging in temperate grassland systems, however, this as yet remains to be quantified. Although these animals mainly disperse dry, inconspicuous, usually small-sized fruits or seeds (Cosyns et al., 2005; Malo \& Suarez, 1995; Pakeman, Digneffe, \& Small, 2002), suchlike seeds are known to suffer high post-dispersal predation rates, too (Hulme \& Benkman, 2002). For instance wood mice (Apodemus sylvaticus) and harvest mice (Micromys minutus) - both known to occur within the 'Westhoek' reserve (Smeers, 2001) - are known to forage for grass seeds in WesternEuropean grasslands (Edwards \& Crawley, 1999). These, as well as any seed or seedling predating group - e.g. insects, birds... - could be responsible for the losses witnessed under open cages. However, the experimental setup did not allow to quantify any of their contributions.

Last, Andresen and Feer (2005) state that "deep burial can also have a negative effect on seedling recruitment by preventing elongating seedlings from reaching the surface". To evaluate this, we must consider the behaviour of $G$. spiniger Marsham, by far the most abundant tunneler in this study. This species constructs brood burrows consisting of a vertical shaft leading to a few horizontal tunnel-like brood chambers, each of the latter being filled with dung to make a horizontal sausage-shaped brood mass (about 100$150 \mathrm{~mm}$ in length and ca. $28 \mathrm{~mm}$ in diameter [Ampe, 2003; Klemperer, 1979]) which provides food for the future larva. These brood chambers are found between 10 and $30 \mathrm{~cm}$ depth (as measured within the study area by Ampe, 2003), depths at which immediate germination of the dung seed content is unlikely to occur (e.g. Grundy, Mead, \& Burston, 2003). The statement of tunnelers having a negative effect on germination is unequivocally shown by our results: in a comparison of both analyses, the difference between the cage types increased when excluding the samples not visited by tunnelers (Fig. 3). Moreover, the between-site differences in tunneler numbers seemed to contribute to the between-site differences in germination: on the moist site, germination was less hampered by tunneler activity than on the dry site (significant interaction of Site and Cage type [interpretation is only meaningful for the analysis including all cages]; Table 2; Fig. 3). Indeed, tunnelers (almost exclusively G. spiniger) were more numerous at the drier site than at the moister site, which is most likely due to hydrological conditions: ground water level comes within reach of the shaft depths during the developmental stage of G. spiniger (September-March; Kühne, 1995) at the moist site, while it does not at the dry site. The contrasting pattern of dweller numbers can subsequently be attributed to the competitive hierarchy underlying the assemblage (see Hanski \& Cambefort, 1991).

In conclusion, the negative short-term effect of tunnelers witnessed in this study is most likely attributed to deep burial. Whether burial 'rescues' seeds from being predated (cf. tropical studies) by means of seed bank enrichment, or is deleterious, remains to be quantified. Also, within one region, contrasting small-scale patterns may occur. If Geotrupes species were absent, and small Onthophagus species were present, for instance, the overall effect on immediate establishment might as well be positive since the latter bury dung to depths that might prove favourable to seedlings. However, since the dominance of Aphodius species is complemented with one or a few deep-tunnelers in many habitats, e.g. Typhoeus typhoeus Linné in heathlands (Brussaard, 1985) and Geotrupes stercorosus Scriba in deciduous forests (Rembialkowska, 1982), the effect of dung beetle activity described here, might prove to hold elsewhere.

\section{Acknowledgements}

We would like to thank the Flemish Ministry of Environment, Nature and Energy, its Agency of Nature and Forest, Coastal Zone Unit for permitting this project in the 'Westhoek', and the Flemish Marine Institute for providing greenhouse accommodations. We are also grateful to Toon Van Daele, Willy Huybrechts, Piet De Becker, Sam Provoost and Marc Leten for providing groundwater data from the WATINA-database. Indispensable practical help came from Bert Delanoeije and his team, Ward Vercruysse and Tanja Milotic of the Research Institute for Nature and Forest, Frank Broucke, Roeland Gunst, Luc Lens, Linda Stroo and Wilfried D'hondt. The manuscript largely improved due to the valuable comments of four anonymous reviewers. The first author has a grant supplied by the Research Foundation - Flanders (FWO). Dries Bonte is a postdoctoral fellow at FWO.

\section{References}

Ampe, C. (2003). Invloed op de bodem door de coprofiele fauna, met speciale aandacht voor Geotrupes sp.. Ghent: Ghent University. 
Andresen, E., \& Feer, F. (2005). The role of dung beetles as secondary seed dispersers and their effect on plant regeneration in tropical rainforests. In P.-M. Forget, J. E. Lambert, P. E. Hulme, \& S. B. Vander Wall (Eds.), Seed fate (pp. 331-349). Wallingford: CABI Publishing.

Andresen, E., \& Levey, D. J. (2004). Effects of dung and seed size on secondary dispersal, seed predation, and seedling establishment of rain forest trees. Oecologia, 139, 45-54.

Bermejo, T., Traveset, A., \& Willson, M. F. (1998). Postdispersal seed predation in the temperate rainforest of Southeast Alaska. Canadian Field-Naturalist, 112, 510-512.

Bornemissza, G. F. (1969). A new type of brood care observed in the dung beetle Oniticellus cinctus (Scarabaeidae). Pedobiologia, 9, 223-225.

Brussaard, L. (1985). A pedobiological study of the dung beetle Typhaeus typhoeus. Ph.D. dissertation. Wageningen University: Wageningen.

Cambefort, Y., \& Hanski, I. (1991). Dung beetle population biology. In I. Hanski, \& Y. Cambefort (Eds.), Dung beetle ecology (pp. 36-50). Princeton: Princeton University Press.

Cosyns, E., Claerbout, S., Lamoot, I., \& Hoffmann, M. (2005). Endozoochorous seed dispersal by cattle and horse in a spatially heterogeneous landscape. Plant Ecology, 178, 149-162.

Edwards, G. R., \& Crawley, M. J. (1999). Rodent seed predation and seedling recruitment in Mesic Grassland. Oecologia, 118, 288-296.

Goss, W. L. (1924). The vitality of buried seeds. Journal of Agricultural Research, 29, 349-362.

Grime, J. P., Hodgson, J. G., \& Hunt, R. (1988). Comparative plant ecology: A functional approach to common British species. London: Unwin Hyman.

Grundy, A. C., Mead, A., \& Burston, S. (2003). Modelling the emergence response of weed seeds to burial depth: Interactions with seed density, weight and shape. Journal of Applied Ecology, 40, 757-770.

Hanski, I. (1991). North Temperate dung beetles. In I. Hanski, \& Y. Cambefort (Eds.), Dung beetle ecology (pp. 75-96). Princeton: Princeton University Press.

Hanski, I., \& Cambefort, Y. (1991). Competition in dung beetles. In I. Hanski, \& Y. Cambefort (Eds.), Dung beetle ecology (pp. 305-329). Princeton: Princeton University Press.

Holter, P. (1977). Experiment on dung removal by Aphodiuslarvae (Scarabaeidae) and earthworms. Oikos, 28, 130-136.

Howe, H. F., \& Smallwood, J. (1982). Ecology of seed dispersal. Annual Review of Ecology and Systematics, 13, 201-228.

Hulme, P. E., \& Benkman, C. W. (2002). Granivory. In C. M. Herrera, \& O. Pellmyr (Eds.), Plant-animal interactions. An evolutionary approach (pp. 132-154). Oxford: Blackwell Publishing.

Janssens, A. (1949). Contribution a l'étude des coléoptères lamellicornes-XIII. Table synoptique et essai de classification pratique des Coléoptères Scarabaeidae. Bulletin de l'Institut Royal des Sciences Naturelles de Belgique, 25(15), $1-30$.

Janssens, A. (1960). Insectes Coléoptères Lamellicornes. Brussels: Institut Royal des Sciences Naturelles de Belgique.
Klemperer, H. G. (1979). Analysis of the nesting-behavior of Geotrupes-Spiniger Marsham (Coleoptera, Scarabaeidae). Ecological Entomology, 4, 133-150.

Kohlmann, B. (1991). Dung beetles in Subtropical North America. In I. Hanski, \& Y. Cambefort (Eds.), Dung beetle ecology (pp. 116-132). Princeton: Princeton University Press.

Kühne, R. (1995). Data to the biology of selected geotrupes species - G. spiniger Marsham, G. vernalis Linné, and G. stercorosus Scriba (Coleoptera, Scarabaeidae, Geotrupini). Deutsche Entomologische Zeitschrift, 42, 343-367.

Littell, R. C., Milliken, G. A., Stroup, W. W., \& Wolfinger, R. D. (1996). SAS system for mixed models. Cary, NC: SAS Institute Inc.

Malcorps, H. (2005a). Klimatologische waarnemingen September 2005, deel I. Brussel: KMI.

Malcorps, H. (2005b). Klimatologische waarnemingen oktober 2005, deel I. Brussel: KMI.

Malo, J. E., \& Suarez, F. (1995). Herbivorous mammals as seed dispersers in a Mediterranean Dehesa. Oecologia, 104, 246-255.

McCune, B., \& Grace, J. B. (2002). Analysis of ecological communities. Oregon: MjM Software Design.

McCune, B., \& Mefford, M. J. (1999). PC-ORD for Windows version 4.26. Oregon: MjM Software.

Page, L. K., Swihart, R. K., \& Kazacos, K. R. (2001). Seed preferences and foraging by granivores at raccoon latrines in the transmission dynamics of the raccoon roundworm (Baylisascaris procyonis). Canadian Journal of ZoologyRevue Canadienne De Zoologie, 79, 616-622.

Pakeman, R. J., Digneffe, G., \& Small, J. L. (2002). Ecological correlates of endozoochory by herbivores. Functional Ecology, 16, 296-304.

Rembialkowska, E. (1982). Energy-balance of the developmental period of Geotrupes-Stercorosus (Scriba) (Scarabaeidae, Coleoptera). Ekologia Polska-Polish Journal of Ecology, 30, 393-427.

SAS Institute. (2003). SAS for Windows version SAS 9.1 TS Level 1M3. Cary: SAS Institute Inc.

Smeers, A. (2001). Onderzoek naar soortensamenstelling en voorkeur voor vegetatietypes van muizen in enkele gebieden in de Vlaamse kustduinen. M.Sc. thesis. Ghent: Ghent University.

Struyve, T. (2002). De coprofiele keverfauna (Insecta: Coleoptera) van enkele duingebieden aan de Westkust en de mogelijke invloed van ontwormingsmiddelen op deze fauna. M.Sc. thesis. Ghent: Ghent University.

Vander Wall, S. B., \& Longland, W. S. (2004). Diplochory: Are two seed dispersers better than one? Trends in Ecology \& Evolution, 19, 155-161.

Wenny, D. G. (2001). Advantages of seed dispersal: A reevaluation of directed dispersal. Evolutionary Ecology Research, 3, 51-74.

Wicklow, D. T., Kumar, R., \& Lloyd, J. E. (1984). Germination of Blue Grama-seeds buried by dung beetles (Coleoptera, Scarabaeidae). Environmental Entomology, 13, 878-881. 